\title{
Ballistic projectiles removal in head and neck region
}

\section{Remoções de projéteis balísticos em região cabeça e pescoço}

\author{
Claudia da Silva OLIVEIRA' ${ }^{1}$ iD 0000-0003-1454-2639 \\ Janielma Azevedo SILVA² ID 0000-0002-5374-4324 \\ Hecio Henrique Araújo de MORAIS1 iD 0000-0002-6450-1483 \\ Erasmo Freitas de SOUZA JUNIOR ${ }^{2}$ iD 0000-0003-1714-9226
}

\begin{abstract}
Injuries caused by firearm projectiles in the head and neck region generally imply severe morbidity and mortality, representing an important public health problem. These injuries can be classified as: penetrating, perforating and avulsive, and the latter is the most worrisome, because they are caused by high-velocity projectiles. Low-velocity projectiles commonly cause penetrating injuries, sometimes remaining lodged in tissues, and their removal may or may not be indicated, depending on factors such as location and severity of the lesion. This paper presents the report of three clinical cases that address injuries caused by low-velocity firearm projectiles, in which they had the indication of this artifact removal, addressing the pre, trans and post-surgery procedures. And we point out that full tactical, technical and theoretical domains are required from the Oral-Maxillofacial Surgeons for being successful in the planning and success in the treatment of these lesions.
\end{abstract}

Indexing terms: Firearms. Maxillofacial injuries. Therapeutics.

\section{RESUMO}

As lesões provocadas por projetil de arma de fogo em região de cabeça e pescoço implicam, geralmente, em morbidade e mortalidades severas representando um importante problema de saúde pública. Esses ferimentos podem ser classificados como: penetrantes, perfurantes e avulsivos, sendo este último o mais preocupante, por serem ocasionados por projéteis de alta velocidade. Os projéteis de baixa velocidade causam comumente ferimentos penetrantes, permanecendo por vezes alojados nos tecidos, podendo ou não, ser indicada a sua remoção, a depender de fatores como localização e gravidade da lesão. O presente artigo traz o relato de três casos clínicos que abordam lesões por projeteis de arma de fogo de baixa velocidade, nas quais tiveram a indicação de remoção do referido artefato, abordando-se as condutas pré, trans e pós-operatórias. Observando-se que é requerido dos Cirurgiões Buco-Maxilo-Faciais, plenos domínios tático, técnico e teórico, para se obter êxito no planejamento e sucesso no tratamento dessas lesões.

Termos de indexação: Armas de fogo. Traumatismos maxilofaciais. Terapêutica.

$\boldsymbol{\nabla} \boldsymbol{\nabla} \nabla \boldsymbol{v}$

1 Universidade do Estado do Rio Grande do Norte, Faculdade de Ciências da Saúde, Curso de Odontologia. Caicó, RN, Brasil.

2 Universidade do Estado do Rio Grande do Norte, Faculdade de Ciências da Saúde, Programa de Pós-Graduação em Saúde e Sociedade da Universidade do Estado do Rio Grande do Norte. Rua Miguel Antônio da Silva Neto, s/n., 59607-360, Aeroporto, Mossoró, RN, Brasil. Correspondence to: EF SOUZA JUNIOR. E-mail: <erasmo_jn@hotmail.com>.

$\mathbf{v} \boldsymbol{\nabla} \boldsymbol{v}$

How to cite this article

Oliveira CS, Silva JÁ, Morais HHA, Souza Junior EF. Ballistic projectiles removal in head and neck region. RGO, Rev Gaúch Odontol. 2022;70:e20220003. http://dx.doi.org/10.1590/1981-86372022000320190161 


\section{INTRODUCTION}

Head and neck regions are relatively common areas for Firearm Projectile (PAF) injuries, which are known for generating severe morbidity and mortality, whether due to homicides, suicides or bodily injuries [1-4]. And, in addition to representing an important public health problem related to the significant morbidity and mortality rate and excessive expenditures for society, they also represent serious challenges for oral-maxillofacial surgeons, given the significant loss of bone tissue and soft tissue, which severity is not always apparent in the initial presentation. Therefore, the reconstruction of these defects is often complicated due to tissue ischemia, necrosis and infection [2,5-7].

Regarding the pathophysiology and magnitude of this type of injury, factors such as caliber, composition, PAFs velocity, shot distance, penetration angle, path and direction of transferred energy, density and size of the affected tissue, should be taken into account for a better understanding of each clinical case, especially in the treatment to be instituted and in the expected prognosis [2,5,7-11].

In this sense, the trauma pattern of PAF wounds is extremely variable, and can be classified as: penetrating, in which the projectile remains lodged in the injured tissue, usually caused by low-velocity projectiles (less than 1000 feet/s); perforating, where there is an entry wound and an exit wound; or avulsive, which involves tissue loss, and the latter is usually caused by high-velocity projectiles (more than 2000 feet/s) $[1,2,6-8,12,13]$.

The initial care of patients with a PAF injury in the head and neck region should focus on the ABCDE of the Advanced Trauma Life Support (ATLS), prepared by the American College of Surgeons, with special emphasis on the establishment of the respiratory tract, and bleeding control and recovery of the hemodynamic state, because the bleeding from the wound and subsequent edema can lead to significant respiratory tract damage, where the loss of large amounts of blood can also cause hypovolemic shock $[1,2,6,13]$.

Another factor to be considered is the fact that injuries caused by firearms are characterized as dirty wounds, because of the possibility of infection, not only by the projectile itself, but also by other contaminants such as of lead and gunpowder remnants, tissue, cartridge and teeth fragments, skin bacteria, and bone spicules, among others. And therefore, they should receive antibiotic and anti-tetanus coverage $[5,9,12]$.

In addition, the care to prevent infections, with the maintenance of volemia for the oxygen transport conservation, wound debridement, debris and tissue fragments removal with no passivity for the maintenance of vitality, reduction and fixation of the stumps, tissues synthesis, drains maintenance, daily cleaning, oral hygiene, and the establishment of adequate nutrition are measures to be taken [1-3,9].

Another important point to be considered in the treatment of this type of injury refers to the projectile removal, and this should be planned when its removal causes less damage to the patient than its maintenance, for example, when they are superficial, implicating the functions of the affected tissues or close to vital structures. Usually, when they occur in events with low-velocity lesions, which cause limited damage along the path traveled with little loss of soft tissue and bone, they are usually treated immediately $[2,3,5,8,9]$.

The immediate and definitive treatment of wounds should be the objective whenever the patient and the scenario allow it, with the proper management of soft and hard tissue damage and proper stabilization of the patient, as they allow the reintegration of patients into society as soon as possible and, therefore, mitigating the socioeconomic and psychological impact of these lesions [1,2].

This study reports the conduct regarding three clinical cases of PAF injury, where projectile removals were justifiably indicated, describing and discussing the tactical, technical and theoretical aspects involved.

\section{CASE REPORTS}

The treatments of these cases occurred at the Emergency and Trauma Hospital Dom Luiz Gonzaga Fernandes, located in the city of Campina Grande, Paraíba, Brazil and the proper authorization for the scientific disclosure of the 
referred clinical cases was obtained through assessment and signature by the patients of the Consent and Free Clarification Statement - TCLE.

\section{First case}

A 29-year-old female patient who was attacked by PAF on the face (Figure 1A) was cared by the Oral-Maxillofacial Surgery and Traumatology service; on tomographic examination it was possible to observe a foreign body compatible with the projectile (Figures 1B; 1C; 1D), which remained housed in the right oral region, with no evidence of significant bone impairment, which was possible to be identified clinically with the touch (Figure 1E). In a mediated manner (after 10 days), we chose to perform under general anesthesia, due to the patient excessive anxiety, the intraoral access (Figure 1F) for the projectile removal (Figure 1G) and posterior suture on all layers (Figure 1H). The removed projectile (Figure 1I) was referred to criminal forensics. In the post-surgery period, dipyrone $1 \mathrm{~g}$ IV every 6 hours for pain control, dexamethasone $4 \mathrm{mg}$ IV every 6 hours for the edema control, ceftriaxone $1 \mathrm{~g}$ every 12 hours for infection prevention and tetanus vaccine of $0.5 \mathrm{ml}$ plus tetanus serum of 5,000IU for tetanus prevention were administered. The post-surgery evolved with good healing and no functional impairment, and she discharged after one day.

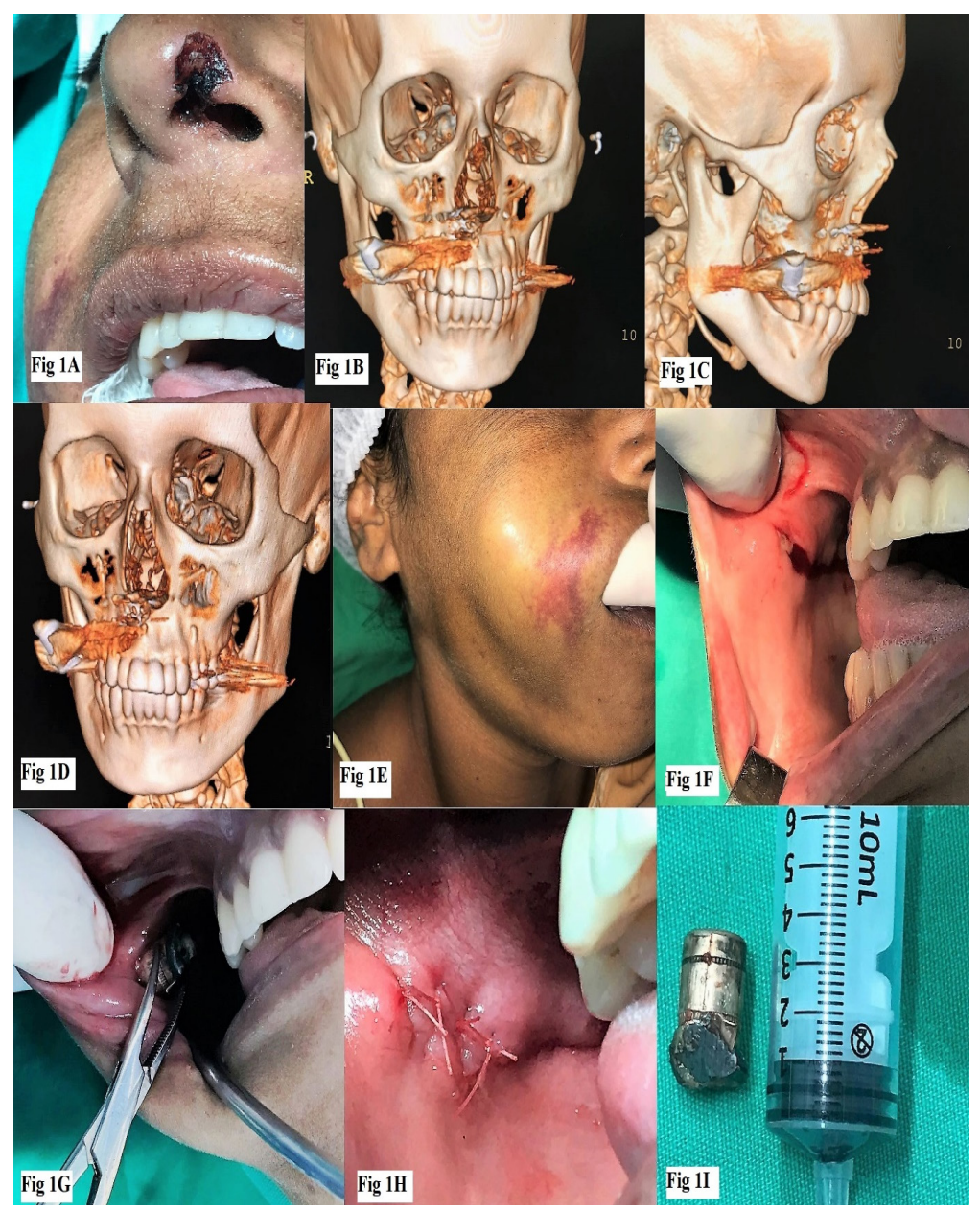

Figure 1. A) Projectile entry wound. B) Computed tomography of the face, demonstrating the projectile trajectory, right oblique lateral view. C) Computed tomography of the face, demonstrating the projectile trajectory, right lateral view. D) Computed tomography of the face, demonstrating the projectile trajectory, left oblique lateral view. E) Palpation of the projectile housed in the oral region. F) Incision with intraoral access. G) Projectile removal. H) Suture on all layers with Catgut absorbable thread. I) Projectile removed for sending it to criminal forensics. 


\section{Second case}

A 26-year-old male patient arrived complaining of "discomfort" in the right mandibular region, showing an increased volume in the bottom of the vestibular furrow. The patient had a history of PAF injury for about 3 years (Figure 2A). A panoramic radiography was requested (Figure 2B), which showed a radiopaque image compatible with PAF. We chose to perform, under local anesthesia, an intraoral access (Figure 2C) for the projectile removal (Figure 2D) and subsequent suture on all layers (Figure 2E) with no major complications. The removed projectile (Figure 2F) was referred to criminal forensics and the patient was discharged on the same day, and cefazoline 500mg every 6 hours for 7 days for infection prevention, dexamethasone $4 \mathrm{mg}$ for edema control, and dipyrone $500 \mathrm{mg}$ for pain control were prescribed.

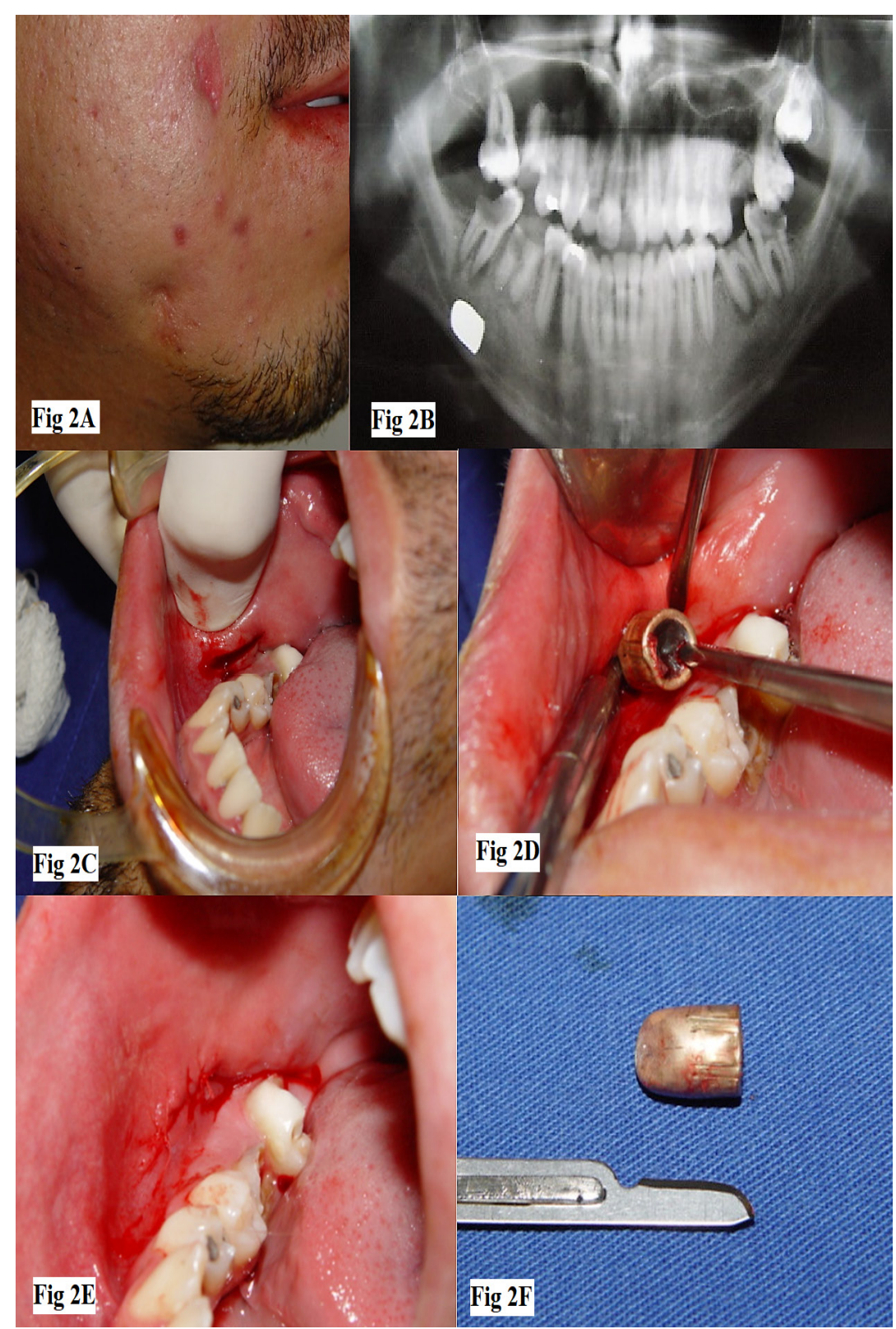

Figure 2. A) Initial aspect of the second intervention, there is a late extra oral scar of the PAF injury. B) Panoramic radiography indicating radiopaque image suggestive of PAF in the right mandibular region. C) Incision with intraoral access. D) Projectile removal. E) Suture on all layers with Catgut-type nonabsorbable thread. F) Projectile removed for sending it to criminal forensics. 


\section{Third case}

A 35-year-old male patient was affected by PAF in the cervical region about 2 years ago, and at that time it was decided not to remove the projectile. After the mentioned period, the patient started to report discomfort due to the superficialization of the projectile that was housed near the thyroid cartilage region (Figure 3A). Under local anesthesia, the incision was made and immediately the projectile was exposed (Figure 3B), which was removed with subsequent suture on all layers (Figure 3C), without no trans and post-surgery complications. The removed projectile (Figure 3F) was referred to criminal forensics and the patient was discharged on the same day, and cefazoline 500mg every 6 hours for 7 days for infection prevention, dexamethasone $4 \mathrm{mg}$ for edema control, and dipyrone $500 \mathrm{mg}$ for pain control were prescribed.

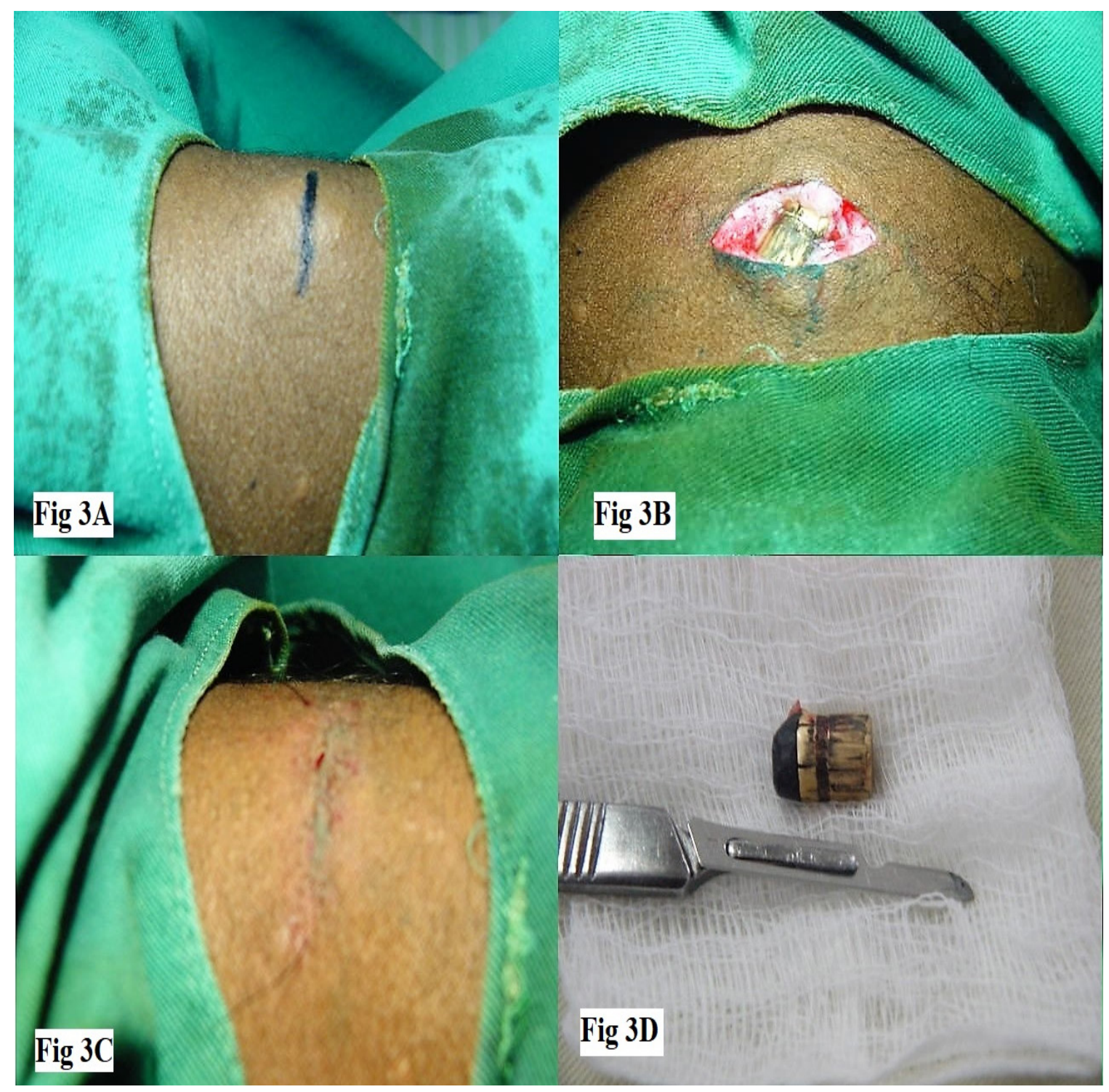

Figure 3. A) Incision demarcation. B) Exposure and removal of the projectile. C) Suture on all layers. D) Projectile removed for sending it to criminal forensics.

\section{DISCUSSION}

The use of firearms associated with crime affects the entire world population. It is estimated that 251,000 people died from firearm wounds in 2016, and Brazil is among the 6 countries leading the global mortality rate due to PAF, 
along with the United States, Mexico, Colombia, Venezuela and Guatemala, totaling $50.5 \%$ of cases. There has been an increase in the number of events over the years, and for example, in 1990 the estimate was 209,000 deaths from firearm wounds, a number much lower than that found today [14].

Globally, most deaths from firearm wounds between 1990 and 2016 occurred more from urban or rural violence, suicides and accidents than from armed conflict. And the year 2001 is pointed out, when deaths from urban or rural violence, self-inflicted and accidental were estimated at 243,000 deaths, while deaths from armed conflicts were estimated at 38,000 [14].

A study by Zamboni et al. [15], which verified fractures in the face, showed that the most affected gender was male (86.6\%), when compared to females (13.4\%) and its incidence was higher in the age group from 21 to 30 years. The main etiology was aggression (38.8\%), followed by car accidents (14.2\%), motorcycle accidents (13.4\%), falls (9\%), hit-and-run accidents (6.7\%), sports accidents (5.2\%), work accidents (5.2\%), firearm wounds (4.5\%) and bike accidents (3\%). Although the incidence of firearm wounds was $4.5 \%$, this is considered a significant number regarding the face injuries.

Regarding injuries in patients that are victims of urban or rural violence, suicides and accidents, these are usually caused by low-velocity projectiles, probably due to their easier access [16]. Such lesions are commonly characterized as penetrating, with the projectile remaining lodged in the individual, as it occurred in the three cases above mentioned [1].

When this occurs, the projectile removal should be considered in situations where the PAF is superficial or impairs the affected structure function. If they have a difficult access lodged deep in the soft tissue, with no functional deficit or important aesthetic defect or there is a proximity to vital structures, it is recommended that the projectile is not removed, keeping it in preservation through image analysis, with computed tomography, digital arteriography, radiography, optical fluorescence and angiography, for example $[1,2,5,8]$.

Clear typifications of these procedures can be found in the reports hereby presented, where in case 1, as the projectile was superficially housed in a region of right oral space, with no damage in any noble structure, the procedure was the removal in order to prevent possible future misfortunes, such as those that occurred in cases 2 and 3 , in which the patients also had superficially housed projectiles, but had to undergo a second surgical intervention. It is valid to point out that the early surgical management of soft tissue in the first stage with less aggressive debridement can decrease morbidity, because it minimizes the final loss of tissue, and a primary closure is preferable over secondary healing, because this can cause excessive healing $[2,16]$.

General anesthesia is recommended for maxillofacial surgeries, and it is of paramount importance that the respiratory tract management is performed correctly, following its various intubation techniques, such as tracheostomy, orotracheal, nasotracheal and submentonian routes, and the professional should choose the most feasible technique to be used according to his indications [17]. The expected effects of general anesthesia are: state of unconsciousness, amnesia, analgesia and immobility [18]. And due to the emotional state, we chose to perform general anesthesia in the first case, since the patient showed excessive anxiety and nervousness.

Regarding the infections prevention, PAF victims should receive broad-spectrum antibiotic prophylaxis and tetanus prophylaxis. The antibiotic administration was justified by the fact that the cases in which the projectile crosses the aerodigestive tract are particularly dangerous, because the devitalized tissue and vascular congestion provide an environment conducive to bacterial growth, and in addition, the involvement of skin injury can potentiate this risk, as it can be seen in the pathogenic degree of this tissue microflora [19].

In the three cases here exposed, the aerodigestive tract was affected, while in cases 1 and 3 there was also skin disruption, in case 1 provided by the projectile, and in case 3 by the surgical procedure for the PAF removal. In all cases it was recommended to use cephalosporins, because this antibacterial group acts with great efficacy against Staphylococcus aureus, producer of penicillinase and greater pathogen of the skin and mucous membranes, and, therefore, the major open wounds colonizer $[19,20]$. Only in case 1 the tetanus prophylaxis was performed, as this was the only one that was presented as a primary intervention, while the others showed no risk for this infection. 
Regarding the edema and pain control, it is believed that the manifestation of inflammation and acute post-surgery pain can be caused due to tissue injury, nerve injury or both, making the post-surgery pain and inflammation management a critical component of patient care. In this sense Hearn et al. [21] found that dipyrone can be successfully used to control post-surgery pain, providing good relief in most individuals. This conclusion is corroborated by Lux et al. [22], after pointing out that $72.2 \%$ of patients when treated with dipyrone were satisfied with the pain therapy. And regarding edema, dexamethasone has been shown as an excellent anti-inflammatory, since this drug acts by inhibiting the action of the Phospholipase A2 enzyme, therefore breaking the rest of the inflammation cascade, and it was also pointed out in the studies by Bhandage et al. [23], which found that dexamethasone acts effectively to control the postsurgery edema and pain in major surgeries involving the maxillofacial region. The last two drugs were chosen for the surgeries performed in this paper.

\section{CONCLUSION}

The head and neck region is often the target of injuries by firearm projectiles, and it is important that the Oral-Maxillofacial Surgeons have the tactical, technical and theoretical mastery of aspects regarding the treatment of PAF injuries. The adopted procedures must be according to a correct planning, taking into account each case. And the projectile removal is indicated in situations where it is superficial or impairs the affected structure function.

\section{Collaborators}

CS Oliveira, was responsible for bibliographic research and for writing the article. JA Azevedo Silva, was responsible for bibliographic research. HHA Morais, was responsible for conducting the case. EF Souza Junior, was responsible for writing and reviewing the article.

\section{REFERENCES}

1. Pires M, Giongo C, Antonello G, Couto R, Filho R, Junior O. An interesting case of gunshot injury to interesting case of gunshot injury to the temporomandibular joint. Craniomaxillofacial Trauma Reconstr. 2014;8(1):79-82. https://doi.org/10.1055/s-0034-1390244

2. Esteban D, Vivar P, Ernesto J, Villasana M, Shadai A, Lumbreras C. Gunshot caused facial wound. Literature review and clinical study of three cases. Reva Odontol Mex. 2017;21(2):125-132. https://doi.org/10.1016/j.ijscr.2011.08.009

3. Vatsyayan A, Adhyapok AK, Debnath SC, Malik K. Reconstruction and rehabilitation of short-range gunshot injury to lower part of face: A systematic approach of three cases. Chin J Traumatol. 2016 Aug 1;19(4):239-43. https:// doi.org/10.1016/j.cjtee.2016.01.016

4. Vorrasi J, Calvi R, Lv M, Hammond R. What Factors necessitate removal of retained ballistic fragments in the head and neck. J Oral Maxillofac Surg. 2018;76(4):819-825. https://doi. org/10.1016/j.joms.2017.11.033

5. Bermejo PR, Coléte JZ, Momesso GAC, Oliveira PA, Fonseca $\mathrm{JH}$, Shinohara EH. Tratamento cirúrgico de fratura mandibular decorrente de projétil de arma de fogo: relato de caso. Arch Heal Investig. 2016;5(6):330-5. https://doi.org/10.21270/archi. v5i6.1718
6. Muddassar M, Arshad R, Rabbani S, Qureshi IS, Khattak IK, Rana Z. Management of gunshot injuries of mandible with open reduction and internal fixation versus closed reduction and maxillo-mandibular fixation. Cureus. 2020;12(4):e7830. https://doi.org/10.7759/cureus.7830

7. Amole O, Osunde O, Akhiwu B, et al. A 14-year review of craniomaxillofacial gunshot wounds in a resource-limited setting. Craniomaxillofac Trauma Reconstr. 2017;10(2):130-137. https://doi.org/10.1055/s-0037-1601341

8. Hanna N, Shuaib W, Han T, Mehta A, Khosa F. Firearms, bullets, and wound ballistics: an imaging primer. Injury. 2015;46 (7):1186-1196. https://doi.org/10.1016/j.injury.2015.01.034

9. Souza Júnior EF, Morais HHA, Lucena EES, Cavalcanti JRLP, Guzen FP, Araújo DP, et al. State of the art in the treatment of mandibular fractures caused by firearms: case report. RGO, Rev Gaúch Odontol. 2018;66(1):88-95. https://doi. org/10.1590/1981-863720180001000123387

10. Grossmann E, Ferreira LA. Surgical treatment of projectile in the infratemporal fossa. Case report. Rev Dor. 2016;17(3):228-31. https://doi.org/10.5935/1806-0013.20160077

11. Wahid FI, Khan MR, Khan MM, Haq NU, Javaid M, Rehman $\mathrm{HU}$, et al. Pattern of firearm injuries in head and neck regions at a tertiary care hospital. J Pak Med Assoc. 2016;66(7):849-52. 
12 Fagin AP, Dierks EJ, Bell RB, Cheng CA, Patel A, Amundson MS. Infection prevalence and patterns in self-inflicted gunshot wounds to the face. Oral Surg Oral Med Oral Pathol Oral Radiol. 2019;128(1):9-13. https://doi.org/10.1016/j.000.2019.02.022

13. Sinnott JD, Morris G, Medland PJ, Porter K. High-velocity facial gunshot wounds: multidisciplinary care from prehospital to discharge. BMJ Case Rep. 2016;2016:bcr2015213268. https://doi.org/10.1136/bcr-2015-213268

14. Nand D, Naghavi M, Marczak LB, Kutz M, Shackelford KA, Arora $\mathrm{M}$, et al. Global mortality from firearms, 1990-2016. J JAMA. 2018;320(8):792-814. https://doi.org/10.1001/ jama.2018.10060

15. Zamboni RA, Wagner JCB, Volkweis MR, Gerhardt EL, Buchmann EM, Bavaresco CS. Epidemiological study of facial fractures at the Oral and Maxillofacial Surgery Service, Santa Casa de Misericordia Hospital Complex, Porto Alegre - RS - Brazil. Rev Col Bras Cir. 2017;44(5):491-7. https://doi. org/10.1590/0100-69912017005011

16. Liu FC, Halsey JN, Hoppe IC, Ciminello FS, Lee ES, Granick MS. A single-enter review of facial fractures as the result of high-speed projectile injuries. Eplasty. 2018;142-50.

17. Kersan L, Ratnasabapathy U. Anaesthesia for maxillofacial surgery. Anaesth Intensive Care Med. 2017;18(9):442-6. https://doi.org/10.1016/j.mpaic.2017.06.010

18. Akeju O, Brown EN. Neural oscillations demonstrate that general anesthesia and sedative states are neurophysiologically distinct from sleep. Curr Opin Neurobiol. 2017;44:178-85. https://doi.org/10.1016/j.conb.2017.04.011
19. Quirke M, Wakai A. Treatment outcome measures for randomized controlled trials of antibiotic treatment for acute bacterial skin and skin structure infections in the emergency department setting. Int J Emerg Med. 2015;8:11. https://doi. org/10.1186/s12245-015-0060-9

20. Campos GBP, Lucena ES, Silva JSP, Gomes P, Germano AR. Efficacy assessment of two antibiotic prophylaxis regimens in oral and maxillofacial trauma surgery: preliminary results. Int J Clin Exp Med. 2015;8(2):2846-2852.

21. Hearn L, Derry S, Ra M, Hearn L, Derry S, Ra M. Single dose dipyrone (metamizole) for acute postoperative pain in adults. Cochrane Database Syst Rev. 2016;4(4):CD011421. https:// doi.org/10.1002/14651858

22. Lux EA, Neugebauer E, Zimmermann M. Pain therapy with metamizole after ambulatory surgery? Schmerz. 2017;31(4):3605. https://doi.org/10.1007/s00482-017-0186-1

23. Bhandage SG, Kurki MS, Sachdeva G, Shetty N, Kundu M, Yadav $A B$. Evaluation of efficacy of peri-operative administration of hydrocortisone and dexamethasone in prevention of postoperative complications in oral and maxillofacial surgeries. Rev Esp Cir Oral y Maxilofac. 2018;40(4):163-8. https://doi. org/10.1016/j.maxilo.2018.01.001

Received on: 27/11/2019

Final version resubmitted on: 9/7/2020

Approved on: 28/7/2020

Assistant editor: Marcelo Sperandio 